\title{
Depositional environment and burial history of a Lower Cretaceous carbonaceous claystone, Bomholm, Denmark.
}

\author{
HENRIK I. PETERSEN, JØRGEN A. BOJESEN-KOEFOED \& HANS PETER NYTOFT
}

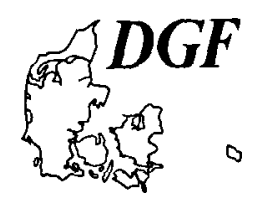

During latest Jurassic time block faulting caused erosion of older strata and formation of the mid-Jurassic unconformity on the island of Bornholm in the Baltic Sea (Gravesen, Rolle \& Surlyk 1982). Deposition probably resumed in the Volgian and continued until the Valanginian. The ?Volgian-Valanginian sediments are assigned to the Nyker Group, which includes the Rabekke, Robbedale and Jydegård Formations (Fig. 1). The sediments of the Nyker Group crop out in the Nyker, Knudsker, Bøsthøj and Arnager-Sose fault blocks (Fig. 2). In the Arnager-Sose block, the ?Volgian-Lower Berriasian deposits are coarse-grained, fluvial sediments of the approximately $20-30 \mathrm{~m}$ thick Homandshald Member of the Rabekke Formation, which unconformably overlies marine sandstones of the Lower Pliensbachian Hasle Formation (Gravesen et al. 1982; Surlyk \& Noe-Nygaard 1986; Surlyk, Amdorff, Hamann, Hamberg, Johannessen, Koppelhus, Nielsen, Noe-Nygaard, Pedersen \& Petersen 1995). The continental sediments of the Homandshald Member gradually pass upwards into a c. $44 \mathrm{~m}$ thick succession dominated by dark grey, but commonly variously coloured, structureless and often sandy clay with silt and sand beds, abundant plant detritus and carbonaceous horizons. These deposits are assigned to the Skyttegård Member of the Rabekke Formation and are of Early and possibly Late Berriasian age (Gravesen et al.1982; Koppelhus \& Batten 1992) (Fig. 


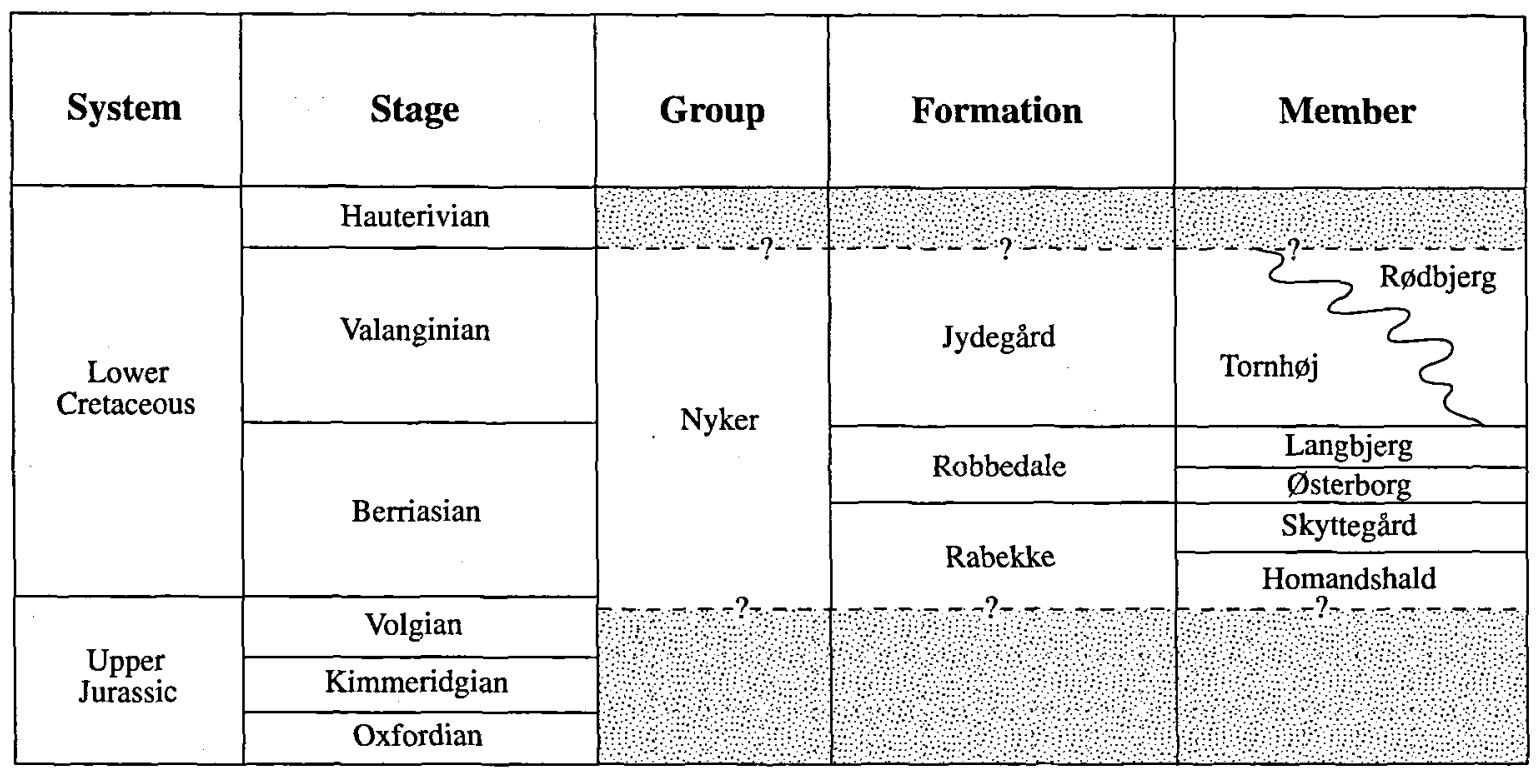

Fig. 1. The Lower Cretaceous stratigraphy of Bornholm (after Gravesen et al. 1982).

1), although previously regarded as being of Late Jurassic age and referred to as the "lower clay series", the "upper member" and the "Purbeck beds" (Christensen 1963; Gry 1956, 1969). The sediments were deposited in lacustrine and swampy environments. Marginal marine conditions may occasionally have occurred (Gravesen et al. 1982).

The black, carbonaceous claystones of the Skyttegård Member have not previously been investigated in detail. This paper presents the results of an organic petrographic and organic geochemical investigation of an approximately $1 \mathrm{~m}$ thick carbonaceous clay bed from the type locality of the Skyttegård Member at
Arnager Bugt. The aims are (1) to interpret the depositional environment of the carbonaceous claystone and (2) to determine the thermal maturity of the organic matter and estimate the burial depth prior to uplift.

\section{Material and analytical methods}

Eight samples were collected for detailed analyses from a poorly exposed c. $1 \mathrm{~m}$ thick carbonaceous claystone situated at the base of a low bluff at Arnager

Table 1. Maceral composition

\begin{tabular}{|c|c|c|c|c|c|c|c|c|c|c|c|c|c|c|c|c|c|c|c|}
\hline \multirow[t]{2}{*}{ Sample } & \multirow[t]{2}{*}{$\begin{array}{c}\text { interval } \\
\text { (cm) }\end{array}$} & \multirow[t]{2}{*}{$\begin{array}{l}\mathrm{H}- \\
\mathrm{mm}\end{array}$} & \multirow[t]{2}{*}{ Tex } & \multicolumn{2}{|c|}{ Texto Eu } & \multirow[t]{2}{*}{ At } & \multirow[t]{2}{*}{ De } & \multirow[t]{2}{*}{ Gel } & \multicolumn{2}{|c|}{$\begin{array}{l}\text { Fl.o- Sp } \\
\mathrm{mm}\end{array}$} & \multirow[t]{2}{*}{$\mathrm{Cu}$} & \multirow[t]{2}{*}{$\operatorname{Re}$} & \multirow[t]{2}{*}{ Lipto } & \multirow[t]{2}{*}{ Fus } & \multirow[t]{2}{*}{ Semi } & \multirow[t]{2}{*}{ In } & \multirow[t]{2}{*}{$\mathrm{Ma}$} & \multirow[t]{2}{*}{$\mathrm{Py}$} & \multirow[t]{2}{*}{ Mi } \\
\hline & & & & & & & & & vol.\% & & & & & & & & & & \\
\hline A-1.8 & $63-65$ & 0 & 5 & 2 & 1 & 14 & 2 & 6 & 2 & 3 & 8 & 1 & 7 & 0 & 0 & 4 & 0 & 2 & 43 \\
\hline A-1,7 & $58-60$ & 2 & 1 & 1 & 0 & 6 & 0 & 2 & 3 & 1 & 4 & 0 & 8 & 1 & 1 & 7 & 1 & 2 & 60 \\
\hline$A-1,6$ & $51-55$ & 8 & 1 & 1 & 0 & 10 & 3 & 5 & 5 & 2 & 3 & 0 & 8 & 1 & 0 & 11 & 2 & 2 & 38 \\
\hline A-1,5 & $46-49$ & 4 & 1 & 5 & 1 & 13 & 6 & 3 & 2 & 1 & 2 & 0 & 6 & 0 & 0 & 5 & 0 & 2 & 49 \\
\hline A-1,4 & $40-42$ & 5 & 1 & 2 . & 2 & 15 & 8 & 4 & 3 & 2 & 5 & 0 & 4 & 0 & 1 & 6 & 0 & 4 & 38 \\
\hline A-1,3 & $29-34$ & 2 & 0 & 24 & 18 & 7 & 4 & 4 & 1 & 1 & 1 & 0 & 1 & 5 & 1 & 5 & 1 & 2 & 23 \\
\hline A-1,2 & $26-28$ & 2 & 0 & 8 & 13 & 8 & 5 & 1 & 1 & 2 & 1 & 0 & 5 & 1 & 0 & 4 & 0 & 3 & 46 \\
\hline A-1,1 & $22-24$ & 5 & 2 & 1 & 0 & 10 & 5 & 2 & 2 & 2 & 2 & 0 & 6 & 1 & 0 & 6 & 0 & 3 & 53 \\
\hline
\end{tabular}

H-mm: huminite-mineral matrix, Tex: textinite, Texto: textoulminite, Eu: euulminite, At: attrinite, De: densinite, Gel: gelinite,Fl. o-mm: fluorescing organo-mineral matrix, Sp: sporinite, Cu: cutinite, Re: resinite, Lipto: liptodetrinite Fus: fusinite, Semi: semifusinite, In: inertodetrinite, Ma: macrinite

Py: pyrite, Mi: other minerals 

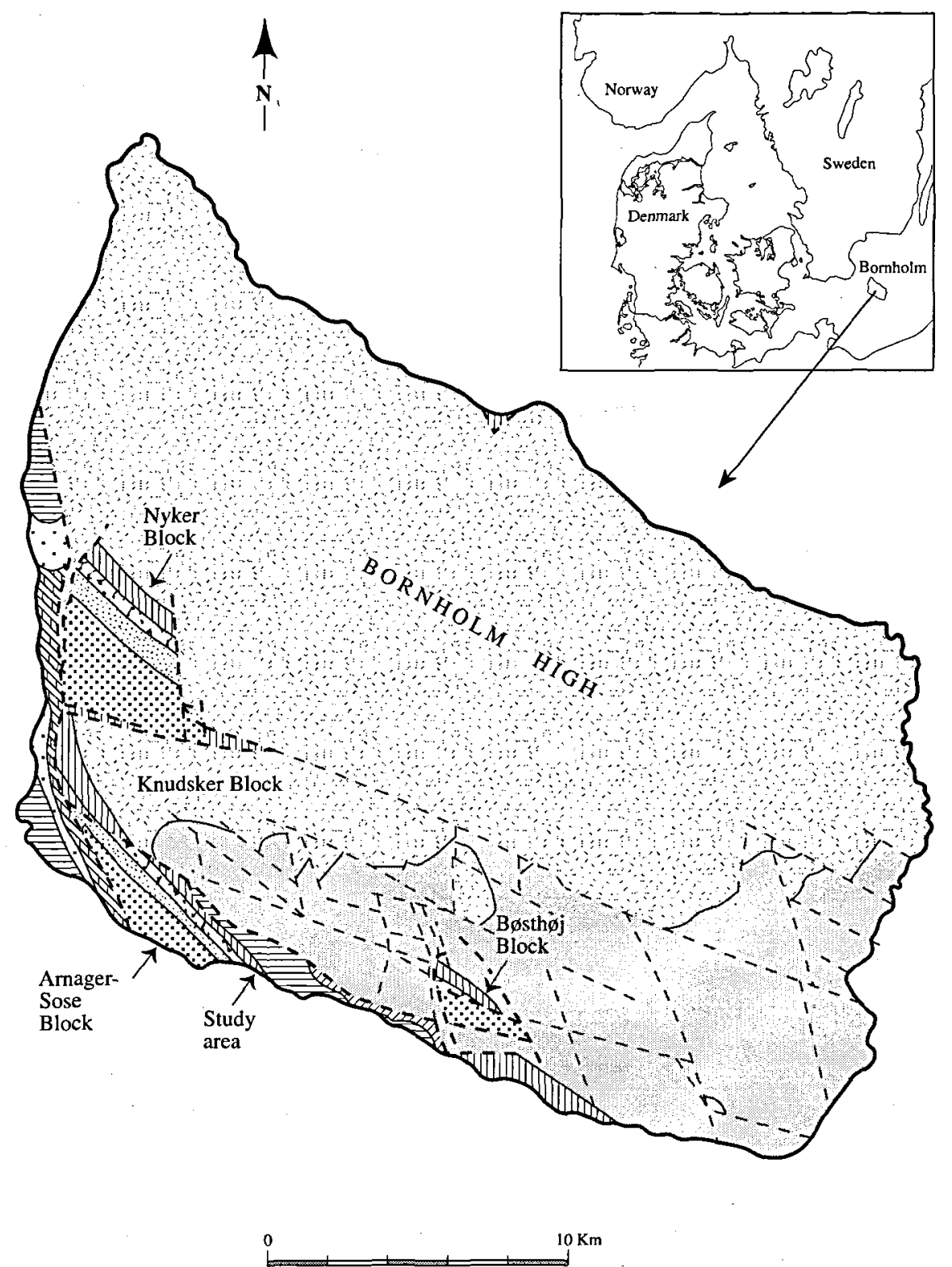

Fig. 2. Geological map of Bornholm showing the fault blocks with Cretaceous deposits (after Gravesen et al. 1982). The location of the studied carbonaceous claystone from the Skyttegård Member is also shown. 
Table 2. Maceral group composition and screening data

\begin{tabular}{|c|c|c|c|c|c|c|c|c|c|}
\hline Sample & $\begin{array}{c}\text { Interval } \\
\text { (cm) }\end{array}$ & Huminite & Liptinite & $\begin{array}{l}\text { Inertinite } \\
\text { vol. } \%\end{array}$ & Minerals & $\begin{array}{l}\text { TOC } \\
\text { wt-\% }\end{array}$ & $\begin{array}{l}\operatorname{Tmax} \\
{ }^{\circ} \mathrm{C}\end{array}$ & $\begin{array}{l}\mathrm{S} 1+\mathrm{S} 2 \\
\mathrm{mg} \mathrm{HC} / \mathrm{g} \\
\text { rock }\end{array}$ & HI \\
\hline $\begin{array}{l}\text { A-1,8 } \\
\text { A-1,7 } \\
\text { A-1,6 } \\
\text { A-1,5 } \\
\text { A-1,4 } \\
\text { A-1,3 } \\
\text { A-1,2 } \\
\text { A-1,1 }\end{array}$ & $\begin{array}{l}63-65 \\
58-60 \\
51-55 \\
46-49 \\
40-42 \\
29-34 \\
26-28 \\
22-24\end{array}$ & $\begin{array}{l}30 \\
12 \\
28 \\
33 \\
37 \\
59 \\
37 \\
25\end{array}$ & $\begin{array}{r}21 \\
16 \\
18 \\
11 \\
14 \\
4 \\
9 \\
12\end{array}$ & $\begin{array}{r}4 \\
10 \\
14 \\
5 \\
7 \\
12 \\
5 \\
7\end{array}$ & $\begin{array}{l}45 \\
62 \\
40 \\
51 \\
42 \\
25 \\
49 \\
56\end{array}$ & $\begin{array}{r}7.81 \\
5.40 \\
18.17 \\
12.90 \\
14.17 \\
39.39 \\
19.37 \\
14.22\end{array}$ & $\begin{array}{l}421 \\
419 \\
418 \\
417 \\
420 \\
394 \\
417 \\
422\end{array}$ & $\begin{array}{r}11.67 \\
9.30 \\
30.75 \\
14.46 \\
15.73 \\
36.04 \\
16.14 \\
14.35\end{array}$ & $\begin{array}{r}137 \\
152 \\
147 \\
101 \\
101 \\
87 \\
78 \\
94\end{array}$ \\
\hline
\end{tabular}

Bugt below the 8.8 milestone on the mainroad between Rønne and Dueodde. Each sample covers 2 to $5 \mathrm{~cm}$ thick intervals within the interval $22-65 \mathrm{~cm}$ above the base of the carbonaceous bed. The samples were embedded in epoxy, and polished blocks were prepared. Each sample was analyzed in reflected white light and fluorescence-inducing blue light in order to determine the kerogen composition (Tables 1,2). A total of 500 points were counted in each sample, and the organic matter was identified according to the standards outlined in Stach, Mackowsky, Teichmüller, Taylor, Chandra \& Teichmüller (1982). The rank was determined by random huminite reflectance measurements on one, euulminite-rich sample (A-1,2). Total organic carbon (TOC, wt-\%) was determined by combustion of carbonate-free samples in a LECO IR-212 induction furnace. Carbonates were removed by several stages of $\mathrm{HCl}$-treatment at $60^{\circ} \mathrm{C}$. Rock-Eval pyrolysis was carried out following the procedures outlined by Espitalié, Deroo \& Marquis (1985). Solvent extracts were prepared by means of a Soxtec instrument, using $\mathrm{CH}_{2} \mathrm{Cl}_{2} / \mathrm{CH}_{3} \mathrm{OH}$ (93 vol./7 vol.) as solvent. Asphaltenes were precipitated by addition of 40 -fold $n$-pentane. The maltene fractions were separated into saturated, aromatic and heteroatomic fractions by medium performance liquid chromatography (MPLC) using a method modified from Radke, Willsch \& Welte (1980). Saturate fractions were analyzed by splitless injection gas chromatography (GC) on a Hewlett Packard 5890 gas chromatograph fitted with a $25 \mathrm{~m}$ HP-1 WCOT column and FID. Saturate and aromatic fractions were analyzed by coupled gas chromatography/mass spectrometry (GC/MS) using splitless injection and a Hewlett Packard 5890 series II gas chromatograph equipped with a $25 \mathrm{~m}$ HP-5 WCOT column and coupled to a Hewlett Packard 5971A quadropole mass spectrometer. The GC and GC/MS results are presented in Table 3 .

\section{Results}

The samples are dominated by minerals which, except for the interval $29-34 \mathrm{~cm}$, make up over $40 \mathrm{vol} . \%$. (Tables 1,2 ). Between $2-4$ vol.\% pyrite, largely framboidal, is present in all samples. Pyrite may also occur in cell lumens in textoulminite. The kerogen is

Table 3. GC and GC/MS parameters

\begin{tabular}{|c|c|c|c|c|c|c|c|c|}
\hline \multirow[t]{2}{*}{ Sample } & \multirow{2}{*}{$\begin{array}{l}\text { Interval } \\
(\mathrm{cm})\end{array}$} & \multirow[t]{2}{*}{$\mathrm{Pr} / \mathrm{Ph}$} & \multirow[t]{2}{*}{$\mathrm{CPI}$} & \multicolumn{4}{|c|}{ Triterpanes, $\mathrm{m} / \mathrm{z} 191$} & \multirow[t]{2}{*}{ Sterane, $\mathrm{m} / \mathrm{z} 217$} \\
\hline & & & & $\begin{array}{l}\mathrm{Tm} /(\mathrm{Tm}+17 \beta \\
(\mathrm{H}) \mathrm{TNH})\end{array}$ & $\begin{array}{l}\mathrm{H} 30 \alpha \beta \prime \\
(\alpha \beta+\beta \alpha)\end{array}$ & $\mathrm{H} 31(\mathrm{~S} / \mathrm{S}+\mathrm{R})^{*}$ & $\mathrm{H} 32(\mathrm{~S} / \mathrm{S}+\mathrm{R})^{* *}$ & \\
\hline$A-1,8$ & $63-65$ & 1.10 & 2.93 & 0.22 & 0.52 & 0.09 & 0.22 & 0.02 \\
\hline $\mathrm{A}-1,7$ & $58-60$ & 1.06 & 2.52 & 0.20 & 0.53 & 0.08 & 0.18 & 0.03 \\
\hline$A-1,6$ & $51-55$ & 1.00 & 2.72 & 0.24 & 0.60 & 0.07 & 0.13 & 0.03 \\
\hline$A-1,5$ & $46-49$ & 1.11 & 2.82 & 0.19 & 0.54 & 0.11 & 0.19 & 0.03 \\
\hline$A-1,4$ & $40-42$ & 0.73 & 2.76 & 0.23 & 0.57 & 0.09 & 0.14 & 0.02 \\
\hline$A-1,3$ & $29-34$ & 1.18 & 2.68 & 0.19 & 0.50 & 0.21 & 0.30 & 0.04 \\
\hline A-1,2 & $26-28$ & 1.16 & 2.81 & 0.15 & 0.54 & 0.06 & $\mathbf{0}$ & 0.01 \\
\hline$A-1,1$ & $22-24$ & 0.70 & 2.80 & 0.19 & 0.55 & 0.07 & 0 & 0.01 \\
\hline
\end{tabular}

* Homohopane $31 \alpha \beta 22 \mathrm{~S} / 22 \mathrm{~S}+22 \mathrm{R}$

** Homohopane $32 \alpha \beta$ 22S/22S+22R

\# Regular sterane $29 \alpha \alpha \alpha 20 S / 20 S+20 R$ 


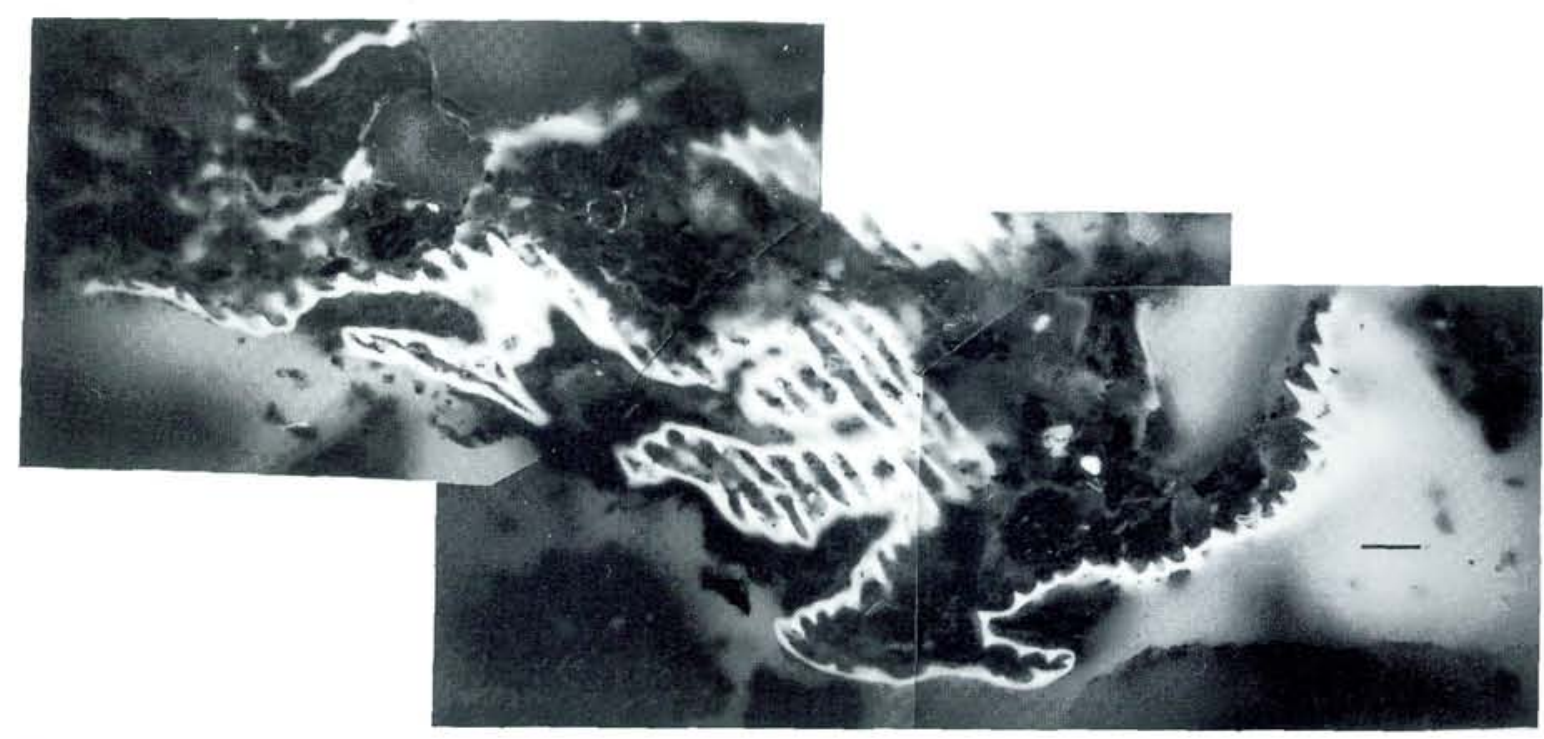

Fig. 3. Microphotograph of a fluorescing cutinite. On the right and left of the photograph, an oblique cut through the cuticle reveals the typical cuticular ledges. In the middle of the photograph, a more or less parallel cut of the cuticle shows how the cuticular ledges form a framework corresponding to the structural pattern of the outer cells of the epidermis. Scale bar $\approx 30 \mu \mathrm{m}$.

composed of huminite, liptinite and inertinite. In general, detrital huminite (attrinite+densinite, average $\mathrm{c}$. 15 vol. $\%$ ) dominates, followed by huminite-mineral matrix (average c. 4 vol.\%) and gelinite (average c. 3 vol.\%). However, the interval $29-34 \mathrm{~cm}$ is characterized by a significantly higher huminite content ( 59 vol.\%), in particular textoulminite and euulminite, compared to other samples. Euulminite and textoulminite may show primary fluorescence. The proportion of liptinite increases upward through the bed (Table 2). The major part of the liptinite is liptodetrinite, commonly of very small particle size ( $<3 \mu \mathrm{m})$, followed by significant amounts of cutinite (Table 1 ). The cutinites are nearly transparent in reflected white light and exhibit a strong yellow to green fluorescence (Fig. 3). They may show signs of biodegradation or transport. Fluorescing organomineral matrix and brown-yellow to yellow fluorescing sporinite are present in all samples. Resinite has only been observed in the uppermost interval. The content of inertinite is in general $\leq 10$ vol. $\%$ and is primarily composed of inertodetrinite (Tables 1, 2).

The TOC content is variable $(5.4-39.4 \mathrm{wt}-\%)$, but is except for the interval $29-34 \mathrm{~cm}$ below $20 \mathrm{wt}-\%$ (Table 2). The samples have Hydrogen Index values (HI) between 78 and 152 with an increasing trend towards the top of the bed (Table 2).

Solvent extract yields are moderate, averaging 81 $\mathrm{mg}$ SOM/g organic carbon. Bulk extract compositions are rather homogeneous, and the asphaltenes average $53 \%$ of the SOM. The maltene fraction is dominated by heteroatomic compounds, which constitute $92 \%$ on average, with saturated and aromatic hydrocarbons on average accounting for $2 \%$ and $6 \%$ respectively. However, the major part of the aromatic fraction consists of sulphur, $\mathrm{S}_{8}$, which upon preparative liquid chromatography behaves similarly to aromatic hydrocarbons.

Distributions of $n$-alkanes are unimodal and strongly heavy-end skewed, with maxima in the $n \mathrm{C}_{25-29}$ range, and a moderate to strong predominance of odd-numbered compounds with values of the Carbon Preference Index $\left(\mathrm{CPI}_{22-32}\right.$ ) between 2.52 and 2.93 (Fig. 4, Table 3). Evaporative losses have probably affected compound distributions in the lower carbon number range, and data should thus be used with caution. Bearing this in mind, acyclic isoprenoids appear very low in abundance, and pristane/phytane ratios are close to unity (Table 3). Cyclic sesquiterpanes and diterpanes are observed in the $n \mathrm{C}_{13-15}$ and $n \mathrm{C}_{17-20}$ ranges, respectively (Fig. 4).

Biomarker concentrations are generally low. Pentacyclic triterpanes monitored by the $\mathrm{m} / \mathrm{z} 191$ fragmentogram are dominated by hopanes, chiefly the $17 \beta(\mathrm{H})$ $21 \beta(\mathrm{H})$ and $17 \beta(\mathrm{H}) 21 \alpha(\mathrm{H})$ configurations, while compounds of the $17 \alpha(\mathrm{H}) 21 \beta(\mathrm{H})$ configuration are of subordinate importance (Fig. 4). Extended hopanes are scarce and strongly dominated by epimers of the 22Rconfiguration. Hence, homohopane and bishomohopane $22 \mathrm{~S} /(22 \mathrm{~S}+22 \mathrm{R})$ epimerization ratios are very low (Table 3). Other maturity-sensitive triterpane ratios such as the $\mathrm{Tm} /(\mathrm{Tm}+17 \beta(\mathrm{H})$-trisnorhopane $)$ ratio and the $C_{30} \alpha \beta /(\alpha \beta+\beta \alpha)$ ratio yield values conformable with the low homohopane epimerization ratios (Table 

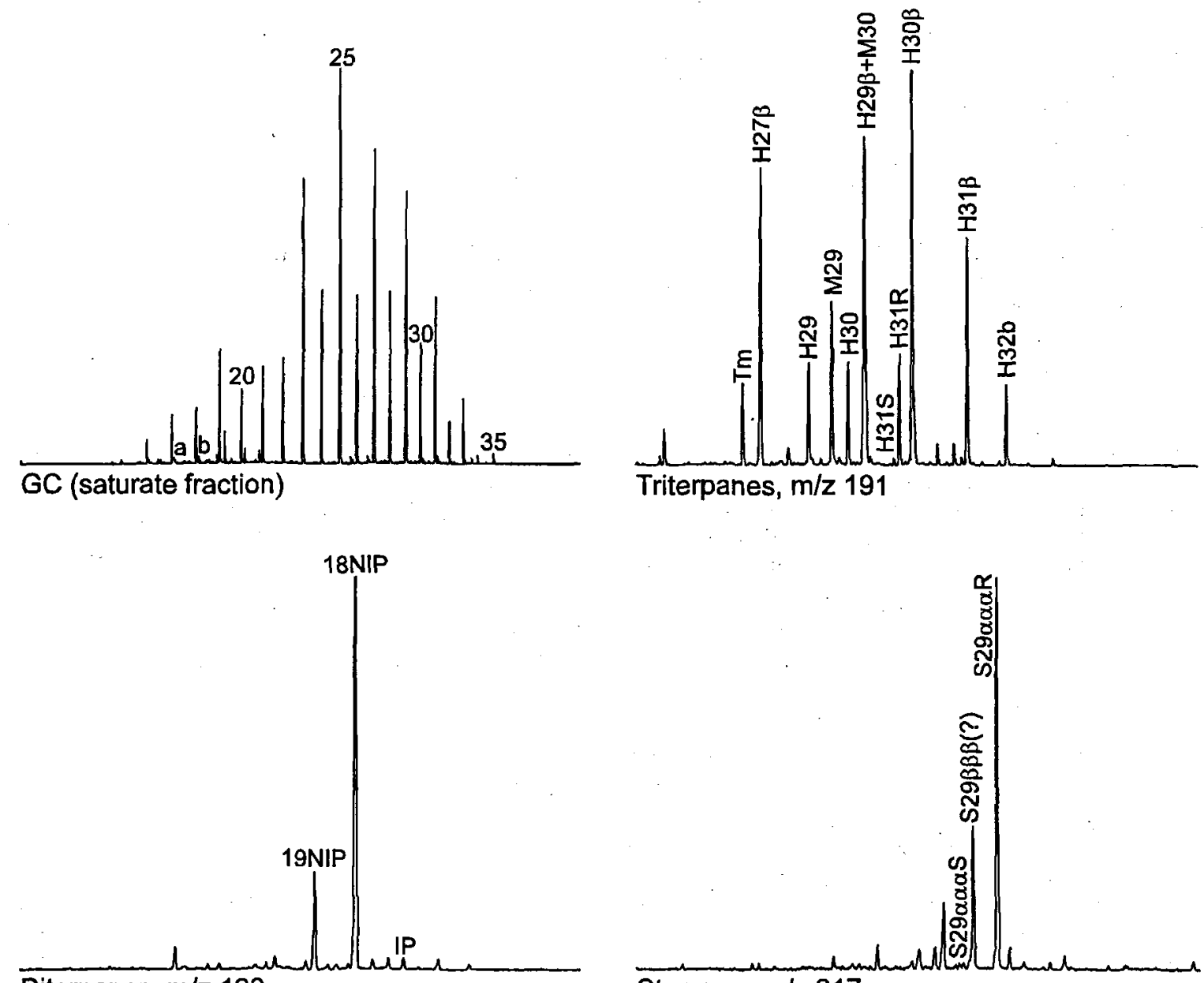

Diterpanes, $\mathrm{m} / \mathrm{z} 123$

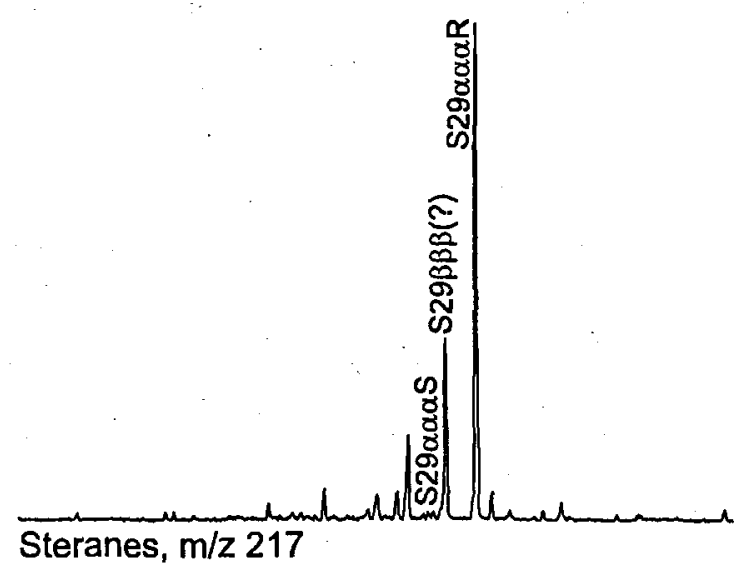

Fig. 4. GC and GC/MS data, sample A-1,1. Gas chromatography, saturated hydrocarbons (upper left): a: pristane; b: phytane; numbers refer to $n$-alkane carbon numbers. Note strongly heavy-end skewed distribution of normal alkanes and low abundance of acyclic isoprenoids. Enhancement of $n \mathrm{C}_{19}$ is due to coelution of 19-norisopimarane (diterpane, see below). Diterpanes, m/z 123 (lower left): 19NIP: 19-norisopimarane; 18NIP: 18-norisopimarane; IP: isopimarane. Other diterpanes are largely absent. Triterpanes, m/z 191 (upper right): Tm: $17 \alpha(\mathrm{H})$-trisnorhopane; $\mathrm{H} 27 \beta: 17 \beta(\mathrm{H})$-trisnorhopane; $\mathrm{H} 29: 17 \alpha(\mathrm{H}) 21 \beta(\mathrm{H})$-norhopane; $\mathrm{M} 29: 17 \beta(\mathrm{H}) 21 \alpha(\mathrm{H})$-norhopane (normoretane); H30: $17 \alpha(\mathrm{H}) 21 \beta(\mathrm{H})-\mathrm{hopane}$; $\mathrm{H} 29 \beta+\mathrm{M} 30: 17 \beta(\mathrm{H}) 21 \beta(\mathrm{H})$-norhopane coeluting with $17 \beta(\mathrm{H}) 21 \alpha(\mathrm{H})$-hopane (moretane); $\mathrm{H} 31 \mathrm{~S}: 17 \alpha(\mathrm{H}) 21 \beta(\mathrm{H}) 22 \mathrm{~S}$ -

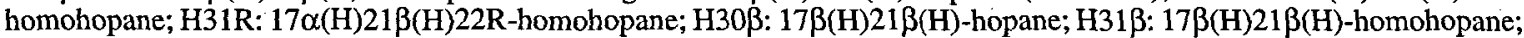
H32 $\beta$ : $17 \beta(H) 21 \beta(H)$-bishomohopane. Note abundance of moretanes and $17 \beta(H) 21 \beta(H)$-hopanes, indicating low thermal maturity. Steranes, m/z 217 (lower right): $\mathrm{S} 29 \alpha \alpha \alpha \mathrm{S}: 5 \alpha(\mathrm{H}) 14 \alpha(\mathrm{H}) 17 \alpha(\mathrm{H}) 20 \mathrm{~S}$-ethylcholestane (trace amount only);

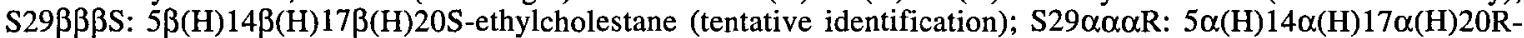
ethylcholestane. Note virtual absence of $\mathrm{C}_{27}, \mathrm{C}_{28}$ and $\mathrm{C}_{30}$ regular steranes, and the near-absence of diasteranes. Low thermal maturity is indicated by the near-absence of $5 \alpha(\mathrm{H}) 14 \alpha(\mathrm{H}) 17 \alpha(\mathrm{H}) 20 \mathrm{~S}$-ethylcholestane. 
3). Hop-17(21)-enes are abundant, and a full series from $C_{27}$ to $C_{31}$ is present. In addition, hop-13(18)enes as well as methylated hop-17(21)-enes are observed, but due to partitioning of hopenes among the 'saturated' and 'aromatic' fractions, quantification has not been attempted. Tricyclic triterpanes are largely absent. Diterpanes, monitored by the $\mathrm{m} / \mathrm{z} 123$ fragmentogram, are dominated by 18-norisopimarane and 19norisopimarane (Fig. 4), one of which coelutes with $n \mathrm{C}_{19}$. Steranes, monitored by $\mathrm{m} / \mathrm{z} 217$ and $218 \mathrm{frag}-$ mentograms, are dominated by ethyl-cholestane of the $5 \alpha(\mathrm{H}) 14 \alpha(\mathrm{H}) 17 \alpha(\mathrm{H})-20 \mathrm{R}$ configuration (Fig. 4). Thus, sterane 20S/(20S+20R) epimerization ratios are very low (Table 3). Presence of $5 \beta(H) 14 \beta(H) 17 \beta-(H)-$ steranes is suspected, rendering $\alpha \beta \beta /(\alpha \alpha \alpha+\alpha \beta \beta)$ sterane ratios unreliable for maturity estimation. Sterenes are abundant and, by analogy to their saturated counterparts, are dominated by $\mathrm{C}_{29}$ ethyl-cholestenes. Hopane to sterane ratios (highest $\mathrm{m} / \mathrm{z} 191$ peak/highest $\mathrm{m} / \mathrm{z} 217$ peak) are rather low, approximately 1-3.

\section{Discussion and conclusions}

\section{Depositional environment and vegetation}

The presence of considerable proportions of humified organic matter in the claystone is the result of deposition in an anoxic environment. Despite the uncertainty with respect to the significance of pristane/phytane and hopane/sterane ratios in relation to environmental interpretations, the low ratios may also point to deposition under conditions of restricted oxygen availability. The terrigenous influence on the depositional environment was strong. Microscopic analyses confirm that the kerogen is exclusively composed of terrestrial organic matter, and the lowest $\mathrm{HI}$ values correspond to huminitic kerogen (kerogen type III) (cf. Mukhopadhyay, Hagemann \& Gormly 1985), whereas the highest $\mathrm{HI}$ values are associated with increased liptinite contents corresponding to exinitic sapropelic kerogen (kerogen type IIb). Similarly, the abundance of long-chain odd-numbered $n$-alkanes, the low abundance of extended hopanes, and the dominance of $\mathrm{C}_{29}$ steranes/sterenes are compatible with a predominance of terrestrial organic matter. However, the association of huminite and in particular syngenetic, framboidal pyrite is generally taken to be evidence of marine influence during deposition (e.g. Casagrande 1987; Brown \& Cohen 1995). This suggests that the claystone was deposited in an anoxic lake situated in a coastal position, which at least on occasion was subject to marine influence and the establishment of brackish conditions. Temporary influence of oxygenated marine water may have supplied the lake with nutrients and raised the $\mathrm{pH}$, resulting in increased bacterial activity and thus biochemical gelification as evidenced by gelinite (Teichmüller 1989).

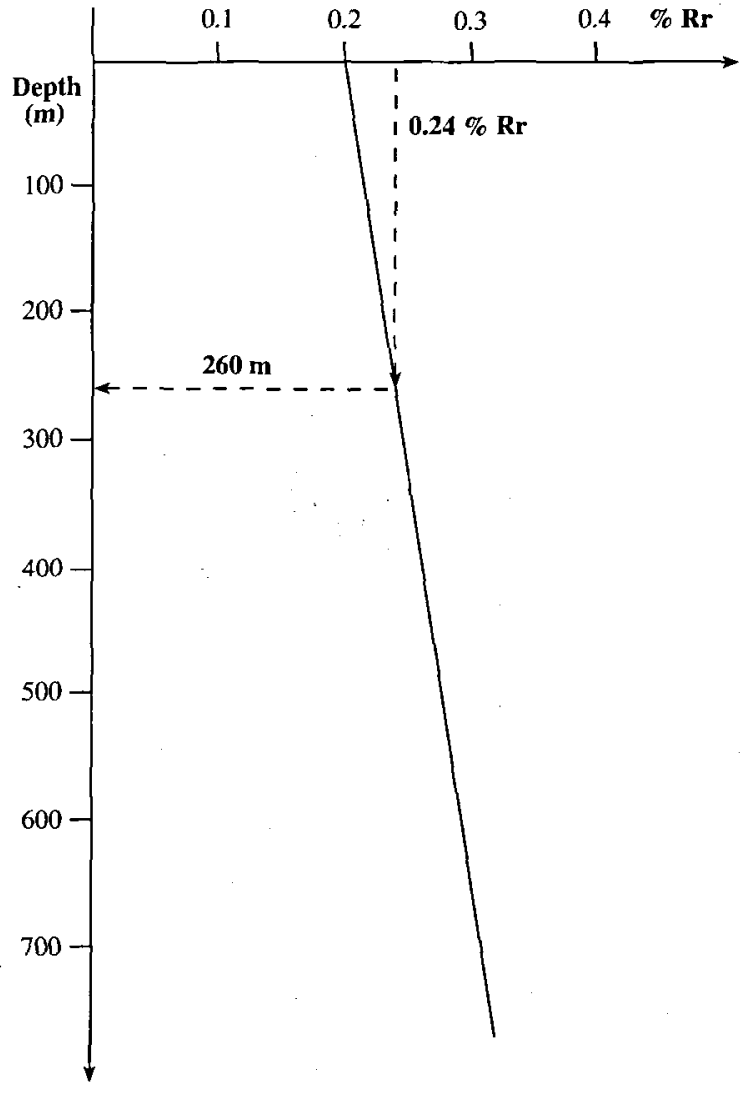

Fig. 5. The regional coalification curve of Petersen et al. (in press) and the mean random reflectance of $0.24 \% \mathrm{Rr}$ used to estimate a maximum burial depth of the claystone of c. $260 \mathrm{~m}$.

The high mineral content, the TOC values and the mainly detrital nature of the organic matter suggest that the plant material in the claystone is primarily allochthonous and that a peat-forming environment did not develop. Although some of the cuticles show signs of transportation, the often delicate cuticles indicate a limited transport distance and together with the fine-grained siliciclastics, point to a low-energy environment. This suggests that the plant remains to a large extent were derived from vegetation which covered the edge of the lake.

The 18- and 19-norisopimaranes biomarkers constitute more than $3 / 4$ of the diterpanes in the samples, and are known as gymnosperm markers (e.g. Noble, Alexander \& Kagi 1986; Killops, Raine, Woolhouse $\&$ Weston 1995). Diterpanes may be derived from leaf waxes, as is also suggested by the comparatively large abundance of cutinite in the samples. Pimarane-type diterpanes occur in the conifer families Pinaceae and Cypressacea, and in the families Podocarpaceae and Araucariaceae (Philp 1994). However, the minor proportions of phyllocladane and kaurane diterpanes, 
whose precursors occur widely in Podocarpaceae, Araucariaceae and Taxodiaceae, suggest a very limited contribution of plant debris from these families. This may point to a source-specific (low-diversity vegetation) contribution of plant material to the depositional environment. A pre-Cretaceous development of angiosperms has been suggested by Martin, Gierl \& Saedler (1989), and isopimaranes and kauranes also occur in angiospermous plants. However, typical angiospermous biomarkers, such as the pentacyclic triterpane oleanane or unsaturated precursors (oleanene, taraxerene) (Philp \& Gilbert 1986; Peters \& Moldowan 1993; Rullkötter, Peakman \& ten Haven 1994), have not been detected, although oleanane tentatively has been detected in Jurassic samples from the Beacon Supergroup, Antarctica (Matsumoto, Machihara, Suzuki, Funaki \& Watanuki 1987). Hence, a gymnospermous flora, chiefly composed of plants from the families Pinaceae and Cypressaceae, probably covered the edge and nearby areas of the lake.

\section{Thermal maturity and burial depth}

The presence of considerable proportions of euulminite in the interval $26-28 \mathrm{~cm}$ (sample A-1,2) made it possible to carry out random reflectance measurements. The mean random reflectance is $0.24 \% \mathrm{Rr}$, corresponding to the peat stage of coalification. Immaturity is also indicated by the transparency of cutinite in white reflected light, and the yellow to green fluorescence under blue light irradiation. Organic geochemical parameters corroborate a low level of thermal maturity. Tmax values between $394^{\circ} \mathrm{C}$ and $422^{\circ} \mathrm{C}$, averaging $416^{\circ} \mathrm{C}$, conform with a very low rank (e.g. Verheyen, Johns \& Espitalié 1984). Low maturity is consistently indicated by both bulk extract compositions and $n$-alkane distributions. The presence of the sterenes and thermally unstable hopenes, abundance of $\beta \beta$-hopanes and moretanes are indicative of a low degree of thermal maturity. The ratio of $30 \beta \beta /(\beta \beta+\beta \alpha$ $+\alpha \beta$ ) is between 0.56 and 0.70 suggesting only limited conversion of the $\beta \beta$-forms. Furthermore, very low homohopane and bishomohopane $22 \mathrm{~S} /(22 \mathrm{~S}+22 \mathrm{R})$ epimer ratios, the ratio of $\mathrm{Tm} /(\mathrm{Tm}+17 \beta(\mathrm{H}) \mathrm{TNH})$ between 0.15 and 0.24 , and the $C_{30} \alpha \beta /(\alpha \beta+\beta \alpha)$ ratios not exceeding 0.60 all testify to immaturity (Table 3 ). In accordance with the slower reactivity of the regular steranes to thermal influence, the $29 \alpha \alpha \alpha(20 S /$ $20 \mathrm{~S}+20 \mathrm{R}$ ) epimer ratios are close to zero (Table 3 ).

The reflectance values of huminite at the surface and the first few hundred metres of burial depth are normally between $0.18 \% \mathrm{R}$ and $0.2 \% \mathrm{R}$ (Dow 1977; Cohen, Raymond Jr., Archuleta \& Mann 1987). The very low thermal maturity of the organic matter, corresponding to the coalification stage of peat, indicates a very shallow burial depth of the claystone (Skyttegård Member). Petersen, Nielsen, Bidstrup \& Thomsen (in press) constructed a regional coalification curve for the Danish Basin and the Fennoscandian Border Zone and used this curve to estimate the maximum burial depth and later uplift of Lower and Middle Jurassic strata. The curve is based on 249 mean random reflectances carried out on huminite/vitrinite in Upper Triassic-Lower Cretaceous sediments in 15 wells in the Danish Basin. Calculation of the burial depth of the Skyttegård Member by means of the mean random reflectance of $0.24 \% \mathrm{Rr}$ and the coalification curve suggests a maximum burial depth of approximately $260 \mathrm{~m}$ (Fig. 5). In the Arnager-Sose fault block the thickness of the Hasle Formation, which unconformably underlies the Rabekke Formation, is $60 \mathrm{~m}$ or more. The Sose Bugt Member (Rønne Formation), which underlies the Hasle Formation in the ArnagerSose fault block, has been buried to approximately $625 \mathrm{~m}$ (Petersen et al. in press). These values suggest that during uplift of the Jurassic deposits, during the latter part of the Jurassic, a maximum of approximately $550 \mathrm{~m}$ of sediments were removed by erosion (Fig. 6). This "missing" sediment package is now represented by the hiatal surface between the Lower Jurassic and ?uppermost Jurassic-Lower Cretaceous strata. Renewed subsidence in the ?latest Jurassic-Early Cretaceous allowed the accumulation of approximately $290 \mathrm{~m}$ of ?uppermost Jurassic-Lower Cretaceous sediments (Fig. 6).

\section{Acknowledgements}

The paper benefited from a constructive criticism by J. R. Ineson, The Geological Survey of Denmark and Greenland (GEUS). A. Andersen (GEUS) is thanked for preparing the drawings. Also thanks to D. KielDühring and L.L. Nielsen (GEUS) for laboratory assistance.

\section{Dansk sammendrag}

Rabekke Formationens Skyttegård Led (Nedre Kridt, Berraisien) på Bornholm består hovedsageligt af mørkegrät, strukturløst sandet ler med silt- og sandlag. Planterester er hyppige, og horisonter med tydeligt forhøjet indhold af organisk materiale forekommer. Sedimenterne blev aflejret i limniske og sumpede miljøer, der dog lejlighedsvis blev påvirket af marine indslag. Et ca. $1 \mathrm{~m}$ tykt, sort lerlag fra typelokaliteten i kystklinten ved Arnager Bugt er blevet undersøgt ved hjælp af organisk petrologiske og geokemiske metoder for at tolke aflejringsmiljøet, termal modenhed og den maksimale begravelsesdybde før hævning.

Det organiske materiale er terrigent, overvejende detritisk, karakteriseret af huminit og cutinit, og kan beskrives som kerogen type III og IIb. Dette under- 
Fig. 6. Schematic illustration of the burial history of the Lower Cretaceous deposits and the underlying Lower Jurassic sediments. At time 1 sediments of the Lower Jurassic Sose Bugt Member and Hasle Formation were deposited. The sediments of the Sose Bugt Member were buried to $c$. $625 \mathrm{~m}$ (time 2) (Petersen et al. in press). Pre-Early Cretaceous uplift resulted in erosion of maximum $550 \mathrm{~m}$ Jurassic sediments (time 3). During renewed subsidence the deposits of the ?uppermost Jurassic-Lower Cretaceous Homandshald Member were buried to $c$. 290 m (time 4; Skyttegård Member c. $260 \mathrm{~m}$ ), followed by a similar amount of uplift.

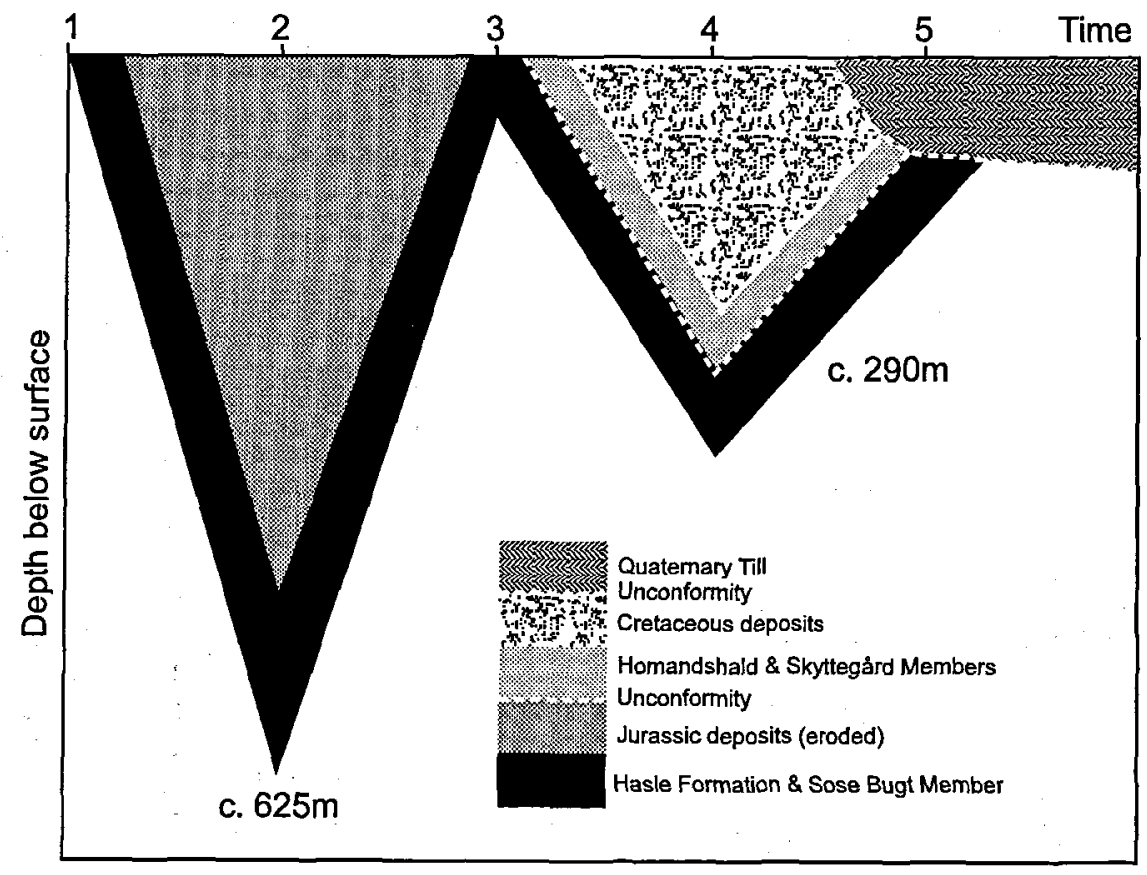

bygges af geokemiske data, der viser en stærk dominans af langkædede $n$-alkaner med et ulige antal kulstofatomer og af $\mathrm{C}_{29}$ steraner/sterener.

Det humificerede plantemateriale, forekomsten af framboid pyrit, velbevarede skrøbelige cuticler samt dominansen af finkornet klastisk materiale peger på aflejring i et kystnært, iltfattigt, lav-energi sømiljø, som periodevist var påvirket af marint vand. Det organiske materiale er transporteret, men transportafstanden var sandsynligvis kort, og plantematerialet antages at hidrøre fra vegetationen langs bredden og de nærliggende områder af søen.

18-og 19-norisopimaranerne udgør over 3/4 af diter-panerne. Disse stoffer stammer fra gymnosperme planter, og forekommer i nåletræsfamilierne Pinaceae og Cypressaceae samt i familierne Podocarpaceae og Araucariaceae. Phyllocladan og kauran, hvis udgangsformer findes i de to sidstnævnte familier, er kun tilstede i meget ringe mængder. Dette kunne pege på, at plantemateriale fra Podocarpaceae og Araucariaceae kun i meget begrænset omfang blev aflejret i søen. Typiske stoffer fra angiosperme planter, som oleanan eller tilsvarende umættede former (oleanen, taraxeren), er ikke fundet i prøverne. Data tyder således på, at det organiske materiale stammer fra en relativ artsfattig, gymnosperm flora.

De transparente cuticler og deres gul-grønne fluorescensfarve peger på, at det organiske materiale er termal umodent. Dette underbygges af en huminitreflektans på $0.24 \% \mathrm{Rr}$ og en gennemsnitlig Tmax på $416^{\circ} \mathrm{C}$. Adskillige geokemiske parametre, såsom meget lave $22 \mathrm{~S} /(22 \mathrm{~S}+22 \mathrm{R})$ homohopan og bishomo- hopan forhold, høje moretan/hopan forhold samt tilstedeværelsen af termalt ustabile forbindelser som sterener, hopener og $\beta \beta$-hopaner, peger ligeledes på en lav termal modenhed. Indkulningsstadiet svarer til tørv, og en beregning ved hjælp af en regional indkulningskurve giver en maksimal begravelsesdybde på ca. $260 \mathrm{~m}$ før hævning. Reflektionsdata antyder endvidere, at maksimalt ca. $550 \mathrm{~m}$ jurassiske sedimenter blev borteroderet, før aflejring af sedimenter blev genoptaget i ?sen Jura-tidlig Kridt.

\section{References}

Brown, K. E. \& Cohen, A. D. 1995: Stratigraphic and micropetrographic occurrences of pyrite in sediments at the confluence of carbonate and peat-forming depositional systems, southern Florida, U.S.A. Organic Geochemistry 22(1), 105-126.

Casagrande, D. J. 1987: Sulphur in peat and coal. In Scott, A. C. (ed.) Coal and coal-bearing strata: Recent advances. Geological Society London Special Publication 32, 87105.

Christensen, O. B. 1963: Ostracods from the PurbeckWealden beds in Bornholm. Danmarks Geologiske Undersøgelse, II. række, $86,58 \mathrm{pp}$.

Cohen, A. D., Raymond Jr., R., Archuleta, L. M. \& Mann, D. A. 1987: Preliminary study of the reflectance of huminite macerals in recent surface peats. Organic Geochemistry $11,429-430$.

Dow, W. G. 1977: Kerogen studies and geological inter- 
pretations. Journal of Geochemical Exploration 7, 79 99.

Espitalié, J., Deroo, G. \& Marquis, F. 1985: La pyrolyse Rock-Eval et ses application, premiere partie. Revue de l'Institut Francais du Petrole 40, 563-579.

Gravesen, P., Rolle, F. \& Surlyk, F. 1982: Lithostratigraphy and sedimentary evolution of the Triassic, Jurassic and Lower Cretaceous of Bornholm, Denmark. Danmarks Geologiske Undersøgelse B7, 52 pp.

Gry, H. 1956: Wealdenaflejringerne på Bornholm. Meddelelser fra Dansk Geologisk Forening 13, 134-141.

Gry, H. 1969: Megaspores from the Jurassic of the island of Bornholm, Denmark. Meddelelser fra Dansk Geologisk Forening 19, 69-89.

Killops, S. D., Raine, J. I., Woolhouse, A. D. \& Weston, R. J. 1995: Chemostratigraphic evidence of higher-plant evolution in the Taranaki Basin, New Zealand. Organic Geochemistry 23(5), 429-445.

Koppelhus, E. B. \& Batten, D. J. 1992: Megaspore assemblages from the Jurassic and lowermost Cretaceous of Bornhom, Denmark. Danmarks Geologiske Undersøgelse A32, 81 pp.

Martin, W., Gierl, A. \& Saedler, H. 1989: Molecular evidence for pre-Cretaceous angiosperm origins. Nature $339,46-48$.

Matsumoto, G. I., Machihara, T., Suzuki, N., Funaki, M. \& Watanuki, K. 1987: Steranes and triterpanes in the Beacon Supergroup samples from southern Victoria Land in Antarctica. Geochimica et Cosmochimica Acta 51, 26632671

Mukhopadhyay, P. K., Hagemann, H. W. \& Gormly, J. R. 1985: Characterization of kerogens as seen under the aspect of maturation and hydrocarbon generation. Erdöl und Kohle - Erdgas - Petrochemie vereinigt mit Brennstoff-Chemie 38(1), 7-18.

Noble, R. A., Alexander, R. \& Kagi, R. I. 1986: Identification of some diterpenoid hydrocarbons in petroleum. Organic Geochemistry 10, 825-829.

Peters, K. E. \& Moldowan, J. M. 1993: The biomarker guide: Interpreting molecular fossils in petroleum and ancient sediments. Prentice Hall, New Jersey, 363 pp.

Petersen, H. I., Nielsen, L. H., Bidstrup, T. \& Thomsen, E. in press: Burial depth and post-Early Cretaceous uplift of Lower-Middle Jurassic strata in the Fennoscandian Border Zone based on organic maturity. In Surlyk, F. et al. (eds) The Jurassic of Denmark and Greenland. Geology of Denmark Survey Bulletin.

Philp, R. P. 1994: Geochemical characteristics of oils derived predominantly from terrigenous source materials. In Scott, A. C. \& Fleet, A. J. (eds) Coal and coal-bearing strata as oil-prone source rocks ?. Geological Society London Special Publication 77, 71-91.

Philp, R. P. \& Gilbert, T. D. 1986: Biomarker distributions in Australian oils predominantly derived from terrigenous source material. Organic Geochemistry 10, 73-84.

Radke, M., Willsch, H. \& Welte, D. H. 1980: Preparative hydrocarbon group type determination by automated medium pressure liquid chromatography. Analytical Chemistry 52, 406-411.

Rullkötter, J., Peakman, T. M. \& ten Haven, H. L. 1994: Early diagenesis of terrigenous triterpenoids and its implications for petroleum geochemistry. Organic Geochemistry $21,215-233$.

Stach, E., Mackowsky, M.-Th., Teichmüller, M., Taylor, G. H., Chandra, D. \& Teichmüller, R. 1982: Stach's text- book of coal petrology. Gebrüder Borntraeger BerlinStuttgart, $535 \mathrm{pp}$.

Surlyk, F. \& Noe-Nygaard, N. 1986: Hummocky crossstratification from the Lower Jurassic Hasle Formation of Bornholm, Denmark. Sedimentary Geology 46, 259273.

Surlyk, F., Arndorff, L., Hamann, N.-E., Hamberg, L., Johannessen, P. N., Koppelhus, E. B., Nielsen, L. H., Noe-Nygaard, N., Pedersen, G. K. \& Petersen, H. I. 1995: High-resolution sequence stratigraphy of a HettangianSinemurian paralic succession, Bornholm, Denmark. Sedimentology 42(2), 323-354.

Teichmüller, M. 1989: The genesis of coal from the viewpoint of coal petrology. In Lyons, P. C. \& Alpern, B. (eds) Peat and coal: origin, facies, and depositional models. International Journal of Coal Geology 12, 1-87.

Verheyen, T. V., Johns, R. B. \& Espitalié, J. 1984: An evaluation of Rock-Eval pyrolysis for the study of Australian coals including their kerogen and humic acid fractions. Geochimica et Cosmochimica Acta 48, 63-70. 